\title{
Smoking and obesity in Chile's Third National Health Survey: light and shade
}

\author{
Vivienne C. Bachelet ${ }^{1}$ and Fernando Lanas ${ }^{2}$
}

Suggested citation Bachelet VC, Lanas F. Smoking and obesity in Chile's Third National Health Survey: light and shade. Rev Panam Salud Publica. 2018;42:e132. https://doi.org/10.26633/RPSP.2018.132

ABSTRACT The Chilean Ministry of Health recently disclosed the first results of the 2016-2017 National Health Survey (Encuesta Nacional de Salud, ENS). The survey was cross-sectional and used a multistage stratified random sampling strategy resulting in a final sample of 6233 persons $\geq 15$ years old, with national, regional, and urban/rural representativeness. The survey results show consistent reductions in tobacco consumption compared to previous national health surveys (ENS 2003 and ENS 2009-2010), most likely due to stringent tobacco control policies enacted in the last 10 years. However, the results also show that there were alarming increases in obesity in the last 15 years. Stronger regulatory policies may be needed to curb the obesity epidemic that besets Chile, along the lines of what was done with tobacco use. The lesson learned seems to be that pushing for stronger policy measures leads to good results, as seems to be the case for tobacco use, while weak measures may not be sufficient for the scale of the health epidemics Chile is now facing, such as excess weight.

Keywords Obesity; public health policy; smoking; Chile.

Recently, the Chilean Ministry of Health presented the first results of the 2016-2017 National Health Survey (Encuesta Nacional de Salud, ENS), also known as the Third National Health Survey or "ENS 2017" (1). The fieldwork for this survey was conducted between August 2016 and March 2017. The first publicly disclosed tabulations show good and bad news for the country and its

\footnotetext{
Facultad de Ciencias Médicas, Universidad de Santiago de Chile, Santiago, Chile. Send correspondence to: Vivienne C. Bachelet, vivienne. bachelet@usach.cl

2 Centro de Capacitación, Investigación y Gestión para la Salud Basada en Evidencias, Universidad de La Frontera, Temuco, Chile.
}

policymakers and most certainly will set the tone for future decisions. The good news is that tobacco consumption shows consistent reductions compared to previous national health surveys, most likely determined by stringent tobacco control policies enacted in the last 10 years. The bad news is that obesity has increased alarmingly in the last 15 years. Stronger regulatory policies may be needed to curb the obesity epidemic that besets Chile, along the lines of what was done with tobacco use.

While the full database and final methods report for ENS 2017 are still not available, there are two important findings that are worthwhile highlighting and putting into context with the previous health surveys (ENS 2003 and ENS 2009-2010 ("ENS 2010")) and with comparative international figures: the reduction of smoking and the increase of obesity. Both conditions have been targeted by policy efforts in Chile because they are known public health challenges and major cardiovascular risk factors, so how they respond to implemented interventions provides important insights on what works and what should be prioritized. This article 1) compares survey results on smoking and overweight/ obesity in Chile based on three national health surveys (ENS 2003, ENS 2010, and ENS 2017), and 2) analyzes the impact of national health interventionsparticularly intersectoral policies and 
regulations-on the prevalence of these two important public health challenges.

According to 2016 World Bank data, Chile has a population of 17.91 million, a life expectancy at birth of 80 years, a fertility rate of 1.8 , and a mortality rate in the under- 5 age group of 8 per 1000 live births (2). Chile has been a member of the Organisation for Economic Co-operation and Development (OECD) since 2009. The OECD data for Chile show that the country has a gross domestic product for 2016 of US\$ 24013 per capita and has one of the highest levels of disparity in the OECD, outranked only by China, India, and South Africa (3).

The Third National Health Survey (ENS 2017) was cross-sectional using a multi-stage stratified random sampling strategy, resulting in a final sample of 6 233 persons $\geq 15$ years old with a national, regional, and urban/rural representativeness. The main survey included 576 questions covering 40 health conditions, 35 risk and protective factors, and nine additional health problems. Two other questionnaires were also administered-one to diagnose mental disorders in the over-18-year-old population, and one for child caretakers to detect developmental delay. In addition, 25 biometric measures were collected for 5520 survey participants. The sex distribution of the sample was $62.9 \%$ women and $37.1 \%$ men, and $23.7 \%$ had fewer than eight years of formal education, $53.3 \%$ had between 8 and 12 years, and $22 \%$ had 12 or more years of schooling.

\section{TOBACCO USE DROPS}

The reduction in the smoking rate was the good news from the ENS 2017 preliminary results. In ENS 2017, 33.3\% of the sample reported smoking cigarettes "daily or occasionally" (Table 1), a downward trend versus ENS 2003 and ENS 2010, which showed a positive response for that variable of $43.5 \%$ and $39.8 \%$ respectively. This drop occurred in both sexes. The proportion of women who reported smoking dropped from 36.5\% in ENS 2010 to 29.1\% in ENS 2017. The greatest reduction in cigarette consumption occurred in the 20-29-year age group (60.5\% in ENS 2010 versus $41.1 \%$ in ENS 2017). The findings for the 15-19-year age group were also encouraging, with smoking decreasing from $35.1 \%$ in ENS 2010 to $22.8 \%$ in ENS 2017. The sampled population in the 30-64-year age group

TABLE 1. Comparison of results on tobacco consumption and nutritional status from the National Health Survey (Encuesta Nacional de Salud, ENS), Chile, 2003-2017

\begin{tabular}{|c|c|c|c|}
\hline \multirow{2}{*}{ Survey variable } & ENS 2003 & ENS 2009-2010 & ENS 2016-2017 \\
\hline & $\%$ & $\%$ & $\%$ \\
\hline \multicolumn{4}{|c|}{ Currently consumes cigarettes daily or occasionally } \\
\hline Men & 48.9 & 43.4 & 37.8 \\
\hline Women & 38.3 & 36.5 & 29.1 \\
\hline Total & 43.5 & 39.8 & 33.3 \\
\hline \multicolumn{4}{|l|}{ Nutritional status } \\
\hline Underweight (BMla: < 18.5) & 2.4 & 1.7 & 1.3 \\
\hline Normal weight (BMI: 18.5-24.9) & 47.2 & 34.0 & 24.5 \\
\hline Overweight (BMI: 25-29.9) & 36.8 & 39.3 & 39.8 \\
\hline Obesity + morbid obesity (BMI $\geq 30)$ & 13.6 & 25.1 & 34.4 \\
\hline
\end{tabular}

Source: Prepared by the authors from figures provided by the Ministry of Health, Chile. Figures available at www.minsal.cl.

also reported smoking less in ENS 2017 versus ENS 2010 (although the reduction was minor), whereas in the over-65-year age group smoking increased slightly in the 2017 survey. Broken down by education, all age strata experienced a reduction in the smoking habit, including those with less than eight years of schooling. There was also a reduction in the proportion of smokers with high tobacco dependency (defined as smoking in the first 60 minutes after waking up in the morning), which dropped from $33.2 \%$ in ENS 2010 to $22.3 \%$ in ENS 2017. The proportion of people reporting passive exposure to smoking also dropped (from $31.0 \%$ in ENS 2010 to $15.2 \%$ in ENS 2017).

\section{MALNUTRITION FROM EXCESS GETS WORSE}

The bad news from the ENS 2017 preliminary results was nutritional status, which was alarming, with 3 of every 4 people sampled showing some type of malnutrition from excess. Specifically, $39.8 \%$ were overweight, $31.2 \%$ were obese, and $3.2 \%$ were morbidly obese. Only 1 in 4 (24.5\%) of the sampled population had a normal weight (body mass index between 18.5 and $24.9 \mathrm{~kg} / \mathrm{m}^{2}$ ). Women had higher levels of obesity than men $(33.7 \%$ versus $28.6 \%)$, and there was a persistent reduction of normal weight with increasing age. While more than half $(54.0 \%)$ of young people (15-19 years old) had a normal weight, this proportion dropped to $37.7 \%$ in the 20-29-year group, and again in later adulthood, with only 1 in 6 people 30-64 years old having a normal weight. There was an inverse correlation between malnutrition from excess and years of education, with the proportion of individuals with normal weight lowest in those with less than eight years of schooling, suggesting a significant health equity problem. Compared to the results for ENS 2003, the rates of obesity have increased strikingly (Table 1).

\section{THE EFFECT OF PUBLIC POLICY}

The country has moved in the right direction with regard to smoking, with even young people reporting lower rates of smoking. Nutrition status, however, appears dismal, with the risk of normalizing obesity on Chile's doorstep. The likely reasons for these contradictory results are examined below.

\section{The case of tobacco}

According to the Pan American Health Organization (PAHO), in 2013, age-standardized prevalence for consumption of tobacco in people $\geq 15$ years old in Chile was 39\%, the highest in Latin America and the Caribbean, followed by Cuba (36\%), and Argentina, Bolivia, and Uruguay (25\%) (4). In 2005, Chile ratified the World Health Organization Framework Convention on Tobacco Control for the Americas. Since then, important public policies have been implemented to reduce the consumption of tobacco (5), and their impact is now being seen. For example, following widespread debate (6), in March 2013, a law was enacted to ban smoking in enclosed public areas (Law 20.660) (7). As a result, Chile now has $100 \%$ smoke-free environments in health and teaching facilities (except for universities), public and private offices, 
restaurants, bars, pubs, and public transportation. Health warnings on cigarette packages are now mandated, and any publicity for tobacco is prohibited, as well as promotion and sponsorship by cigarette brands on television, radio, printed press, billboards, and points of sale. In addition, selective consumption taxes were levied on cigarettes, increasing the final price to the consumer (4).

The question remains whether these policies actually led to lower rates of smoking among youth and the adult population. This has yet to be explored in Chile. Ecological studies, which can provide insight on tobacco control and smoking prevalence, could be conducted to help confirm this very important association using the results of the ENS 2017. Cross-sectional studies would also be useful. A multi-country cross-sectional study with a very interesting design (community audits and surveys of adult smokers 35-70 years old) found an association between tobacco control policy implementation and quit rates (former versus ever smokers) (8). This study, which included Chile in the sample, concluded that implementation of tobacco control measures is generally poor, but that higher quit ratios are related to more extensive controls, greater social unacceptability of smoking, and greater knowledge of smoking harms.

Another study based on data from the Global Youth Tobacco Survey found that exposure to tobacco marketing is positively and significantly associated with both smoking intensity and the probability of experimenting with tobacco (9). The ENS 2017 results for the younger age groups could provide fresh and robust evidence to support this association, as marketing of tobacco products in Chile was severely curtailed after enactment of Law 20.660.

\section{Obesity is knocking on our door}

Chile is not alone in the growing prevalence of obesity worldwide $(10,11)$. Together with Argentina and Mexico, Chile has one of the highest prevalence rates of obesity in Latin America (12). Increased food energy supply (13) and the consumption of sugary beverages have been found to be associated with an increase in average body weight $(12,14,15)$. A systematic review found that the intake of free sugars or sugarsweetened beverages is a determinant of body weight (16), so the fact that Chile is one of the three countries in the world with the highest per capita consumption of sugar (17) is not good news.

Obesity, smoking, and sedentary lifestyles, among other factors, are wellknown risk factors for diabetes and cardiovascular disease (11). A recently published study that looked at the impact of tobacco use, sedentary lifestyles, obesity, and alcohol consumption on diabetes in the Chilean population, using data from ENS 2010, found that about $23 \%$ of the population-attributed fraction of diabetes could be prevented if obesity did not exist (18). The cross-sectional CESCAS I study conducted in Argentina, Chile, and Uruguay found a high prevalence of diabetes that was significantly associated with older age, lower educational attainment, and overweight and obesity, among other factors (19).

In this context, Chilean lawmakers decided to increase taxes on sugarsweetened nonalcoholic beverages by $5 \%$, in 2014 (20), and mandate front-ofpackage black-colored warning messages (Figure 1) on high sugar, calorie, fat, and salt content, by 2016 (21). Evidence on the effects of these regulatory measures is described below.

A recent evidence-informed policy brief provided an overview of literature on the effects of increasing taxes on sugar-sweetened beverages and found that

\section{FIGURE 1. Warning labels on unhealthy foods in Chile ${ }^{a}$}
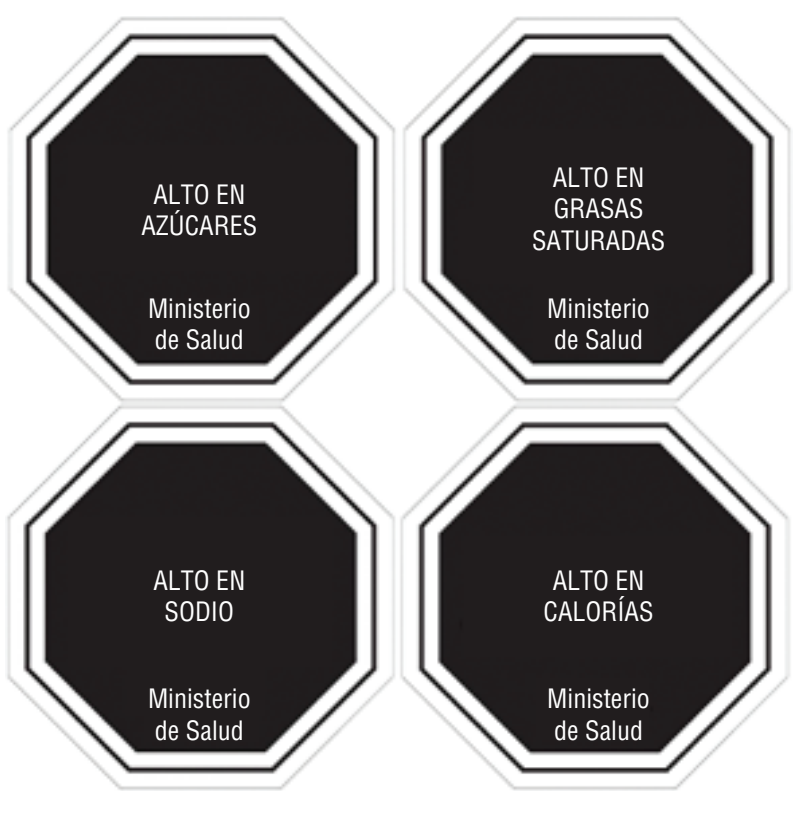

a This image can be found in the public domain. volumetric taxes (e.g., a tax of 10 cents / liter) were more effective than ad valorem taxes (those based on a percentage of final price) in producing an impact on population weight (20). However, a 2013 systematic review found limited evidence to support the effectiveness of taxation on curbing obesity (22). A more recent cross-country comparison analysis found inconclusive indications that taxing energy-dense foods and sugar-sweetened beverages generally had the desired effects on prices and consumption of targeted products (23). A 2016 systematic review on the effectiveness of sugar-sweetened beverage taxation in nine middle-income countries found that a $10 \%$ increase in beverage prices decreased consumption from 5-39 kilojoules per person per day (24). The authors of the review conclude, nonetheless, that additional research, with survey data, is needed to ascertain whether increasing taxes on sugar-sweetened beverages can lead to a permanent effect on the prevalence of obesity. A recently published study from California compared sales of sugar-sweetened beverages before and after volumetric taxation and found that prices increased and sales of taxed beverages generally declined, while sales of untaxed beverages did not (24); however, the dietary and health impacts are unknown. 
In the case of Chile, the impact of health warning labels on the consumption of unhealthy foods is yet to be explored. A recent study found that front-of-package content for many of these foods includes child-directed marketing (e.g., popular children's characters) along with health-oriented appeals, suggesting a disconnect between health policy and marketing messages (25). The effect of taxes also requires further research. Given the correlation between higher taxes and health impact, Chile's $5 \%$ levy on sugar-sweetened nonalcoholic beverages may need to be increased to deter consumers from high-energy foods and sugar-sweetened beverages.

\section{CONCLUDING REMARKS}

People in Chile are not happy with the first results of the 2017 National Health Survey. After so many efforts to boost the public health system after decades of market-oriented policies in the sector, it would appear that the health ministry's job of making our population healthier is not producing the expected results. While investing in the health care system is always important, it appears that today the challenges our country faces must be approached with intersectoral policy measures. The lesson learned for us is that pushing hard policy measures leads to good results, as might be the case of tobacco use, while weak measures may

\section{REFERENCES}

1. Ministerio de Salud (CL). Tercera Encuesta Nacional de Salud establece prioridades sanitarias para la próxima década. 22 Nov. Santiago: MINSAL; 2017. Available from: http://www.minsal.cl/tercera-encuestanacional-de-salud-establece-prioridadessanitarias-para-la-proxima-decada / Accessed on 24 June 2018.

2. World Bank. World Development Indicators database: country profile, Chile [Internet]. Washington: World Bank; c2018. Available from: http://databank. worldbank.org/data/views/reports / reportwidget.aspx?Report_Name=Count ryProfile\&Id=b450fd57\&tbar $=y \& d d=y \& i$ $\mathrm{nf}=\mathrm{n} \& \mathrm{zm}=\mathrm{n} \&$ country $=\mathrm{CHL}$ Accessed on 24 June 2018.

3. Organisation for Economic Co-operation and Development. OECD economic surveys: Chile 2018 [Internet]. Paris: OECD Publishing; 2018. Available from: http:// dx.doi.org / 10.1787 / eco_surveys-chl2018-en Accessed on 24 June 2018.

4. Pan American Health Organization. Report on tobacco control for the Region of the Americas-WHO Framework Convention on Tobacco Control: 10 years later. Washington: PAHO; 2016. Available from: http: / /iris.paho.org/xmlui/handle/ $123456789 / 28393$

5. Nazzal C, Harris JE. Lower incidence of myocardial infarction after smoke-free legislation enforcement in Chile. Bull World Health Organ. 2017;95(10):674-82. doi: 10.2471/BLT.16.189894.

6. Ahuja RV, Kollath-Cattano CL, Valenzuela MT, Thrasher JF. Chilean news media coverage of proposed regulations on tobacco use in national entertainment media, May 2011-February 2013. Tob Control. 2015;24(5):521-2. doi: 10.1136/ tobaccocontrol-2014-051861.

7. Ministerio de Salud (CL). Ley $N^{\circ} 20.660$, Modifica Ley $\mathrm{N}^{\mathrm{o}} 19.419$ en materia de ambientes libres de humo de tabaco. 8 Feb. Santiago: MINSAL; 2013. Available from: https:/ / www.leychile.cl/ Navegar?
idNorma $=1047848 \&$ idParte $=$ Accessed on 24 June 2018. A, Igumbor E, Chifamba J, et al. Tobacco control environment: cross-sectional survey of policy implementation, social unacceptability, knowledge of tobacco health harms and relationship to quit ratio in 17 low-income, middle-income and high-income countries. BMJ Open. 2017;7(3):e013817. doi: 10.1136/bmjopen2016-013817.

9. Plamondon G, Guindon GE, Paraje G. Exposición a la publicidad de tabaco y consumo de tabaco en adolescentes en América del Sur. Salud Publica Mex. 2017;59 Suppl 1(Suppl 1):80-7. doi: $10.21149 / 7735$.

10. Ng M, Fleming $T$, Robinson $M$, Thomson B, Graetz N, Margono C, et al. Global, regional, and national prevalence of overweight and obesity in children and adults during 1980-2013: a systematic analysis for the Global Burden of Disease Study 2013. Lancet. 2014;384(9945):766-81. doi: 10.1016/S0140-6736(14)60460-8.

11. World Health Organization. Global status report on noncommunicable diseases 2014. Geneva: WHO; 2014. Available from: http:/ /www.who.int/nmh/publications / ncd-status-report-2014/en/

12. Fisberg M, Kovalskys I, Gómez G, Rigotti A, Cortés LY, Herrera-Cuenca M, et al. Latin American Study of Nutrition and Health (ELANS): rationale and study design. BMC Public Health. 2016;16:93. doi: 10.1186/s12889-016-2765-y.

13. Vandevijvere $S$, Chow CC, Hall KD, Umali E, Swinburn BA. Increased food energy supply as a major driver of the obesity epidemic: a global analysis. Bull World Health Organ. 2015;93(7):446-56. doi: 10.2471/BLT.14.150565.

14. Lanas F, Bazzano L, Rubinstein A, Calandrelli M, Chen CS, Elorriaga N, et al. Prevalence, distributions and determinants of obesity and central obesity in the
8. Chow CK, Corsi DJ, Gilmore AB, Kruger not be sufficient for the scale of the health epidemics we are now facing, such as excess weight. Probably in the next national survey, we can expect to see the effects of the second generation of policies put in place in Chile to curb obesity. This is just another expression of the need for health in all policies, as the World Health Organization correctly points out.

\section{Conflicts of interest. None.}

Disclaimer. Authors hold sole responsibility for the views expressed in the manuscript, which may not necessarily reflect the opinion or policy of the RPSP / PAJPH or the Pan American Health Organization (PAHO).
Southern Cone of America. PLoS One. 2016;11(10):e0163727. doi: 10.1371/journal. pone. 0163727

15. Corvalán C, Garmendia ML, Jones-Smith J, Lutter CK, Miranda JJ, Pedraza LS, et al. Nutrition status of children in Latin America. Obes Rev. 2017;18 Suppl 2:7-18. doi: 10.1111/obr.12571.

16. Te Morenga L, Mallard S, Mann J. Dietary sugars and body weight: systematic review and meta-analyses of randomised controlled trials and cohort studies. BMJ. 2012;346:e7492. doi: 10.1136/bmj.e7492.

17. Urbina S. Chile es uno de los países que lideran el consumo de azúcar en el mundo [news release]. 5 Jan. Santiago: El Mercurio S.A.P. Available from: http://www. economiaynegocios.cl/noticias/noticias. asp?id=324265

18. Bertoglia MP, Gormaz JG, Libuy M, Sanhueza D, Gajardo A, Srur A, et al. The population impact of obesity, sedentary lifestyle, and tobacco and alcohol consumption on the prevalence of type 2 diabetes: analysis of a health population survey in Chile, 2010. PLoS One. 2017;12(5):e0178092. doi: 10.1371/journal. pone.0178092.

19. Irazola V, Rubinstein A, Bazzano L Calandrelli M, Chung-Shiuan C, Elorriaga $\mathrm{N}$, et al. Prevalence, awareness, treatment and control of diabetes and impaired fasting glucose in the Southern Cone of Latin America. PLoS One. 2017;12(9):e0183953. doi: 10.1371/journal.pone.0183953.

20. Bascuñán J, Cuadrado C. Effectiveness of sugar-sweetened beverages taxes to reduce obesity: evidence brief for policy. Medwave. 2017;17(8):e7054. doi: 10.5867/ medwave.2017.08.7054.

21. Pérez-Escamilla R, Lutter CK, RabadanDiehl C, Rubinstein A, Calvillo A Corvalán C, et al. Prevention of childhood obesity and food policies in Latin America: from research to practice. Obes Rev. 2017;18 Suppl 2:28-38. doi: 10.1111/ obr.12574. 
22. Maniadakis N, Kapaki V, Damianidi L, Kourlaba G. A systematic review of the effectiveness of taxes on nonalcoholic beverages and high-in-fat foods as a means to prevent obesity trends. Clinicoecon Outcomes Res. 2013;5:519-43. doi: 10.2147/CEOR.S49659.

23. Hagenaars LL, Jeurissen PPT, Klazinga NS. The taxation of unhealthy energy-dense foods (EDFs) and sugar-sweetened beverages (SSBs): an overview of patterns observed in the policy content and policy context of 13 case studies.
Health Policy. 2017;121(8):887-94. doi: 10.1016/j.healthpol.2017.06.011.

24. Nakhimovsky SS, Feigl AB, Avila C, O'Sullivan G, Macgregor-Skinner E, Spranca M. Taxes on sugar-sweetened beverages to reduce overweight and obesity in middle-income countries: a systematic review. PLoS One. 2016; 11(9):e0163358. doi: 10.1371/journal.pone. 0163358.

25. Mediano Stoltze F, Barker JO, Kanter R, Corvalán C, Reyes M, Taillie LS, et al. Prevalence of child-directed and general audience marketing strategies on the front of beverage packaging: the case of Chile. Public Health Nutr. 2018;21(3):454-64. doi: 10.1017/S1368980017002671. Epub 2017 Nov 2.

Manuscript submitted 28 February 2018. Revised version accepted for publication on 24 June 2018.
RESUMEN

\section{El tabaquismo y la obesidad en la tercera Encuesta Nacional de Salud de Chile: luces y sombras}

Palabras clave Obesidad; políticas públicas de salud; fumar; Chile.
El Ministerio de Salud chileno divulgó recientemente los primeros resultados de la Encuesta Nacional de Salud 2016-2017 (ENS). Se trataba de una encuesta transversal, en la cual se usó una estrategia de muestreo polietápico aleatorio y estratificado, cuyo resultado fue una muestra final de 6233 personas $\geq 15$ años, con representatividad nacional, regional y urbana o rural. Los resultados de la encuesta muestran reducciones constantes en el consumo de tabaco en comparación con encuestas nacionales de salud anteriores (la ENS 2003 y la ENS 2009-2010), muy probablemente debido a las políticas estrictas de control del tabaco sancionadas en los últimos 10 años. Sin embargo, los resultados también indican que la obesidad aumentó de forma alarmante en los últimos 15 años. Es posible que se necesiten políticas regulatorias más firmes para reducir la epidemia de obesidad que se registra en Chile, de manera similar a lo que se hizo con el consumo de tabaco. Pareciera que la enseñanza extraída es que impulsar medidas políticas más firmes conduce a buenos resultados, como parece ser el caso del consumo de tabaco, mientras que las medidas débiles pueden ser insuficientes para la escala de las epidemias en el ámbito de la salud a las que Chile se enfrenta ahora, como el sobrepeso.
RESUMO

Tabagismo e obesidade na Terceira Pesquisa Nacional de Saúde do Chile: luzes e sombras

Palavras-chave
O Ministério da Saúde do Chile divulgou recentemente as conclusões preliminares da Pesquisa Nacional de Saúde (PNS) 2016-2017. Foi conduzida uma pesquisa de delineamento transversal com uma estratégia de amostragem aleatória estratificada com múltiplos estágios, resultando em uma amostra final de 6.233 indivíduos com 15 anos de idade ou acima de representatividade nacional, regional e urbana/rural. Os resultados de pesquisa demonstram uma redução constante do tabagismo em relação às pesquisas nacionais anteriores (PNS 2003 e PNS 2009-2010), provavelmente decorrente das políticas de controle rigoroso do tabagismo promulgadas na última década. Porém, os resultados também indicam um aumento alarmante da obesidade nos 15 últimos anos. Políticas de regulamentação mais rigorosas devem ser necessárias para conter a epidemia de obesidade que assola o país, na mesma linha do que foi feito com o tabagismo. $\mathrm{O}$ ensinamento a ser tirado parece ser o seguinte: a pressão para que sejam adotadas políticas mais duras leva a bons resultados, como no caso do tabagismo, e medidas brandas não são suficientes diante da magnitude das epidemias em saúde enfrentadas atualmente pelo país, como o excesso de peso. 